\title{
Artificial Intelligence for a Better Employee Engagement
}

\author{
Ria Emilia Sari, Siu Min, Hiskia Purwoko, Asnan Furinto, Dewi Tamara \\ Magister Manajemen BINUS Business School, Universitas Bina Nusantara, Jl. Hang Lekir I \\ No. 6, Senayan, Kebayoran Baru, Jakarta Selatan, DKI Jakarta, Indonesia
}

\begin{tabular}{l}
\hline A R T I C L E I N F O \\
\hline Keywords: \\
engagement, \\
employee engagement, \\
work engagement, \\
technology, \\
technology enabler, \\
artificial intelligence, \\
software, application. \\
Kata Kunci: \\
Keterikatan, \\
Keterikatan karyawan, \\
Keterikatan pekerjaan, \\
teknologi, \\
teknologi yang memampukan, \\
Inteligensi artifisial, \\
Perangkat lunak, Aplikasi
\end{tabular}

Corresponding author: dtamara@binus.edu
A B S T RACT

Employee engagement is the positive attitude of each employee towards the business and the value of the organization. This research aims to see whether the use of Al-based technology, tools, and software can help management detect intangible things such as employee engagement level and provide clues as to what factors influence it and how management can improve it. This research is a qualitative approach. We interviewed the management and selected employees to determine employee engagement at SML before and after implementing the AI-based application. The interview results compared with the results obtained from the application for six months (Feb - July 2020). The study was conducted on all SML employees, amounting to 39 people. This research has shown that the use of AIbased software can significantly help management, not only to find out the status of each employee's level of involvement but also to anticipate their attitudes and behaviors through predictive indicators. Thus, the company can proactively retain key employees. This research provides new and practical insights and opportunities for company owners and leaders to utilize technology to detect something that is naturally quite difficult because it requires specific knowledge and experience.

\section{SARI PATI}

Keterikatan karyawan adalah sikap positif setiap karyawan terhadap bisnis dan nilai organisasi. Penelitian ini bertujuan untuk melihat apakah penggunaan teknologi, alat, dan perangkat lunak berbasis AI dapat membantu manajemen mendeteksi hal-hal yang tidak berwujud seperti tingkat keterikatan karyawan dan memberikan petunjuk tentang faktor-faktor apa yang mempengaruhinya dan bagaimana manajemen dapat memperbaikinya. Penelitian ini adalah pendekatan kualitatif. Kami mewawancarai manajemen dan karyawan yang dipilih untuk menentukan keterikatan karyawan di SML sebelum dan sesudah menerapkan aplikasi berbasis AI. Hasil wawancara dibandingkan dengan hasil yang diperoleh dari aplikasi selama enam bulan (Feb Juli 2020). Penelitian dilakukan terhadap seluruh karyawan SML yang 
berjumlah 39 orang. Penelitian ini menunjukkan bahwa penggunaan software berbasis AI dapat membantu manajemen secara signifikan, tidak hanya untuk mengetahui status tingkat keterikatan setiap karyawan tetapi juga untuk mengantisipasi sikap dan perilaku mereka melalui indikator prediktif. Dengan demikian, perusahaan dapat secara proaktif mempertahankan karyawan kunci. Riset ini memberikan wawasan dan peluang baru dan praktis bagi pemilik dan pimpinan perusahaan untuk memanfaatkan teknologi guna mendeteksi sesuatu yang secara alami cukup sulit karena memerlukan pengetahuan dan pengalaman khusus.

(c) 2020 IRJBS, All rights reserved.

\section{INTRODUCTION}

Employee engagement is one of the factors that greatly influence company performance. Research shows that companies with highly engaged employees are 43\% more productive («Employee Commitment Remains Unchanged...» Watson Wyatt Worldwide. 2002. Archived from the original on 2007-09-27. Retrieved 2006-11-07.). That is why a high level of engagement, especially from key employees, is very important to be built and maintained. This becomes even more critical if the key employee is not easily replicated. Requires special expertise and competence as well as customer relationships accumulated with increasing flight hours. Of course, they have a high value, so that they are also vulnerable to offers from outside the company. If they have a very high commitment to work and the company, research shows that their performance level is $20 \%$ higher and $87 \%$ lower, they are likely to leave the company (Lockwood, 2007).

Sinergi Multi Lestarindo (SML) is an Indonesian private limited company, having their headquarter in Jakarta and branch office in Surabaya, Indonesia. Established in 2013 under the Sinaco holding group, SML began its business by distributing specialty chemicals in seafood \& meat processing, confectionery, beverage, seasoning, toiletries, healthcare, supplement to exclusive personal care, and cosmetics.
Besides partnering with various strategic manufacturers companies worldwide, SML also has built its research and development team to provide the best formulation and always update on the trend in the market to catch its development for the international market in SML advanced laboratories. Over the years, SML continues to grow, progress with the ever-changing market demand, unceasingly explore and craft new products that are valuable, relevant to the client's needs, and improve their product performance to a better one.

SML is basically a trading business in chemical products. Its performance is very much determined by the salespeople who must be very masters in the field of products they sell. To achieve a high level of competence requires a willingness to learn, experience, and high dedication to the company. The company operational scope is as described in the Figure-1.

SML trading scheme was started from a material selection, where a rigorous selection is carried out in determining cooperation with suppliers because SML has the responsibility to be able to deliver selected products that have been certified or checked in terms of quality and provide more benefits in developing a product within a manufacturing company in Indonesia. For this reason, SML has its evaluation team in determining cooperation, namely starting with product traceability until the quality checking of 


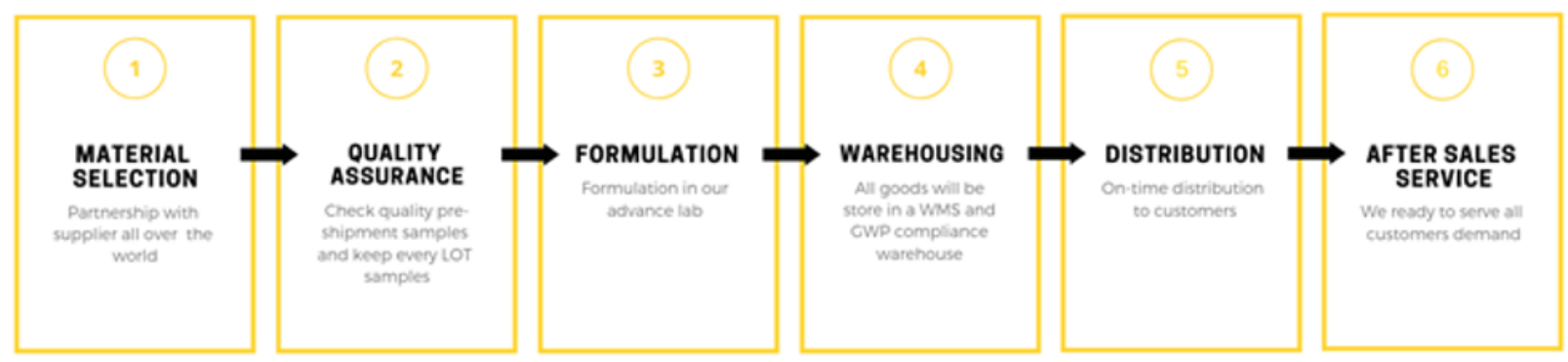

Figure 1. SML Operational Scope

the products before being handed over to the customer. To be able to compete in the market, SML also provides a qualified application laboratory to be able to create superior products from a combination of various suppliers who have worked with them. This laboratory is very useful for small and medium-scale companies that currently do not have a laboratory for product development, so they can have the same opportunity to compete with large-scale companies in terms of creating new products through the laboratory provided by SML. Apart from that, SML also has several warehouses close to its customers, making it easier for access and minimizing lead time by creating buffer stocks so that it can avoid empty goods.

Sales is the backbone of company performance and responsible for supplier sourcing up to the project approved by the customers. In this industry, they are the contested talents. That's what unsettles the CEO of SML, Mr. Siu Min, who feels that he and the company must do something to be able to obtain and retain the best talents. «Just one of them left. I'm dizzy. Operations were immediately disrupted, and I couldn't easily find a replacement immediately, «he said. In 2020 the composition of SML employees is shown in Figure-2, and the sales force turnover rate in 2019 is shown in Figure-3.

Mr. Siu Min added, according to him, the salary or total benefits of the salespeople actually quite competitive. The exit interview also shows that salary is not the main factor that keeps them going. But if they leave, not only is the effect immediately felt on the company's performance, but also the cost of finding a replacement and its development is also not cheap. In addition, those who have left have also spread a bad atmosphere to their friends through provocative gossip or contra-productive attitudes. They said negatively about the company that there is no point in continuing to work there because of the favoritism of management, unfair systems, jobs that do not give hope for future careers. Affected employees become restless and unfocused, resulting in impaired collaboration and performance. Some have even begun to think about the possibility of leaving and moving to other companies. This condition is often difficult to detect. So the company can be late in anticipating it. "Well, can we prevent or anticipate such things in advance? Is there a practical way to help me with this?" Asked Mr. Siu Min worried.

During its operation since 2013, SML has never had a standard in assessing employee job satisfaction, which in turn has an impact on employee engagement. SML only has an employee job appraisal based on performance, which is done once a year. This can only be assessed from one point of view where the company never knows whether there is an indication that the employee is satisfied, uncomfortable, a toxic person, or a tendency to resign. For this reason, SML management applies AI-based software to detect, maintain and improve employee engagement levels, especially key employees, the salespeople.

\section{LITERATURE REVIEW}

\section{$\mathrm{AI}$ as Technology Enabler for Decision Making}

The use of technology, including AI, has increasingly 


\section{EMPLOYMENT COMPOSITION BY DIVISION}

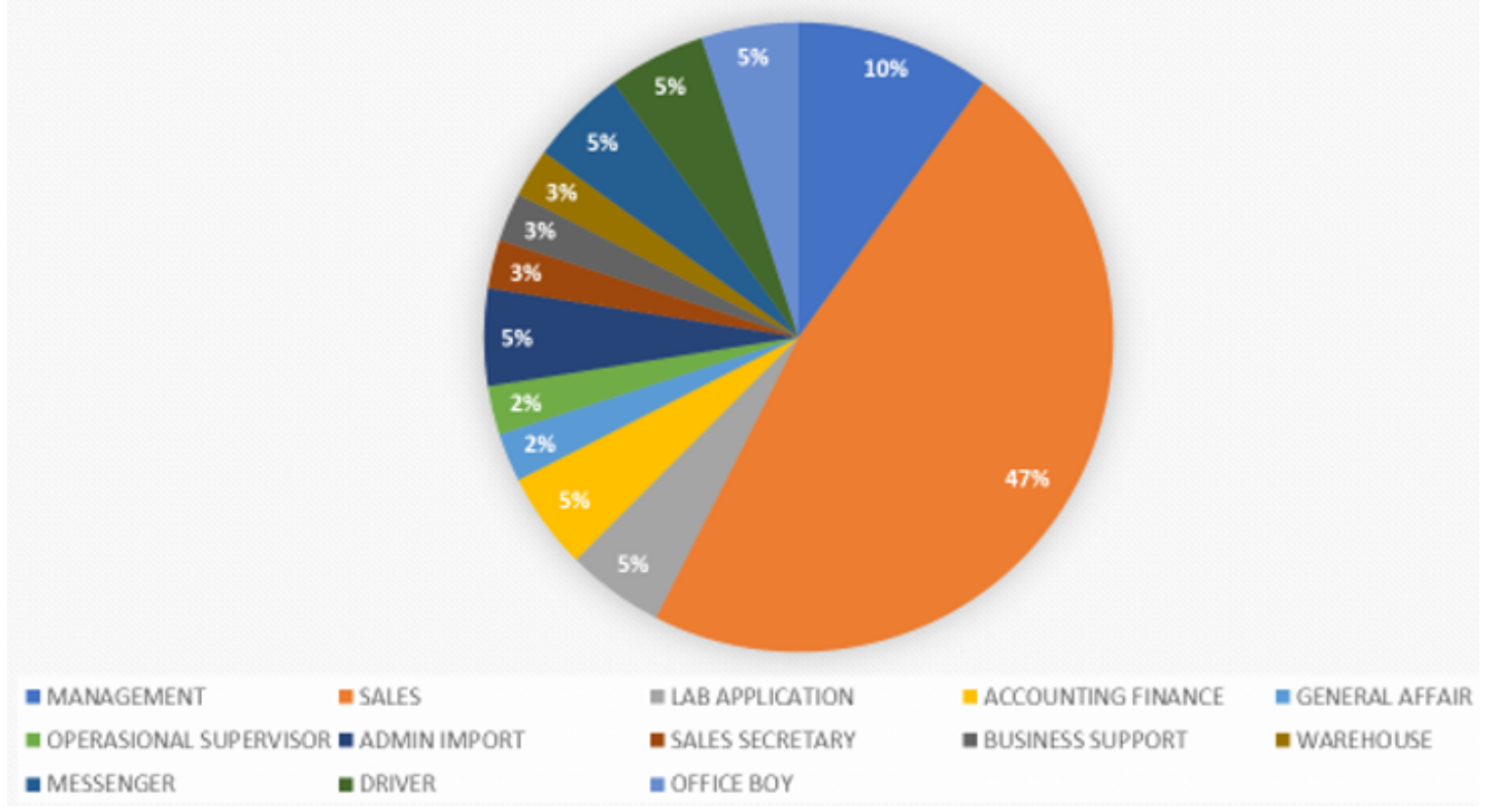

Figure 2. SML employee composition

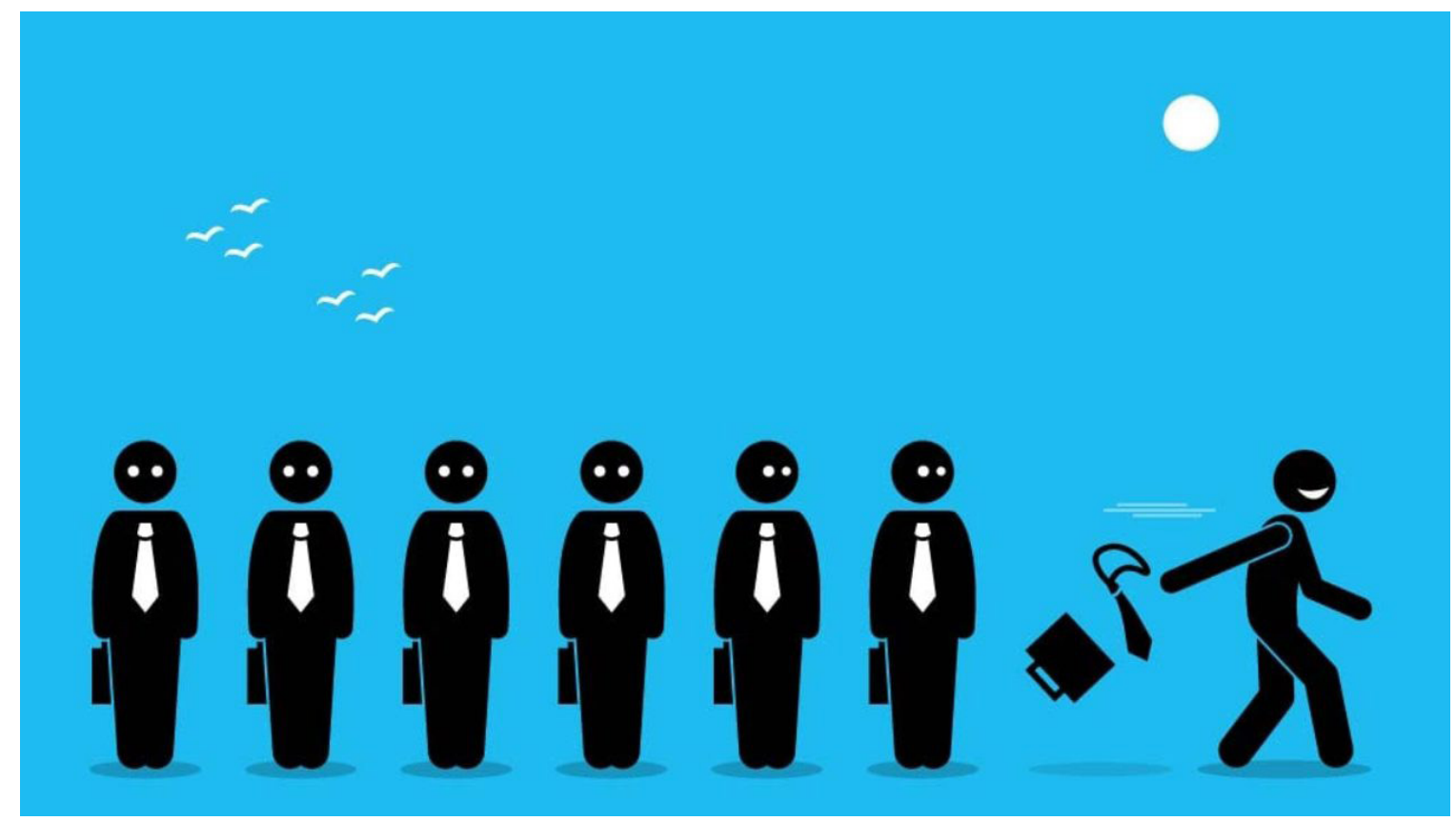

Figure 3. SML salespeople turnover rate

helped leaders make decisions more quickly and accurately. This is increasingly felt if the data or information that is processed is large, complex, and dynamic. In this case, the need for intelligent machine assistance is increasingly greater because the ability of the human brain will not be able to handle it. Technology becomes an enabler for humans to make decisions by minimizing as much as possible human judgement. 


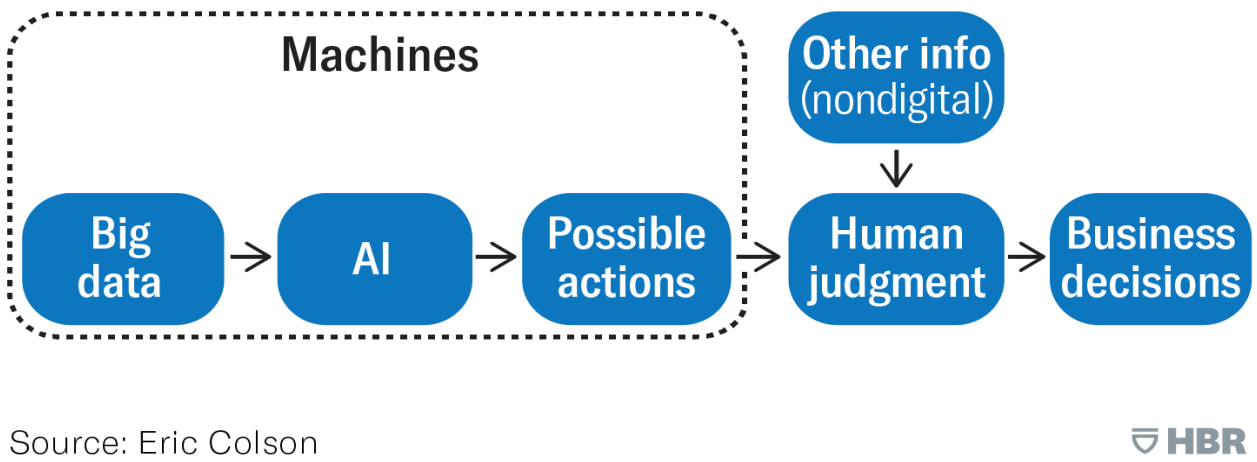

Figure 4. A Decision-Making Model That Combines the Power of AI and Human Judgement

Eric Colson is Chief Algorithms Officer at Stitch Fix, who prior was Vice President of Data Science and Engineering at Netflix, provides a decision-making model that places machines and people in their place (see Figure 4).

Research provides data that most companies have difficulty handling big data or data analytics. 41\% of CEOs said they were not ready to utilize new data analytic tools, and only $4 \%$ said that they were "mostly" prepared.

For the HR field, the application of AI has its own complexity, where any theory and practice become more complex when applied to human objects. Rejection or conflict can arise when an individual must accept the decision of a "machine."

\section{Al Challenges in HR Practices}

The complexity of the application of $\mathrm{AI}$ in the HR field increases because it is in contact with many abstract or complex things. For example, $\mathrm{AI}$ is associated with measurement results about something abstract like "good employees" or "employee satisfaction" or what we will discuss further, "employee engagement."

\section{Employee Engagement}

An "engaged employee" is fully absorbed by and enthusiastic about their work and so takes positive action to further the organization's reputation and interests and has a positive attitude towards the organization and its values. (Paul, 2017)

According to their attitude and behavior, Gallup divides employee engagement level into three groups:

1. Actively Disengaged employees are those who continue to undermine the company and other employees through their openly dissatisfied attitudes and behavior. They are like thorns in the flesh or poison spreaders in the company. They drain the positive energy for nothing.

2. Disengaged employees are those who have the mentality of salary workers. They are not destructive but also do not provide superior difference. Ordinary. Their energy is average.

3. Engaged employees are those who are passionate, enthusiastic, make a significant difference. Their existence and activities give very positive energy. They are the determinants of company excellence. We dedicate themselves to the company. The better future is in their hands.

There is a psychological connection between the employee and his/her job. Employees can feel happy or stressed when carrying out their duties. It will affect the level of employee satisfaction at work and, finally, their performance.

Gallup did research, and it was proven that companies with engaged employees had many advantages, among others: 


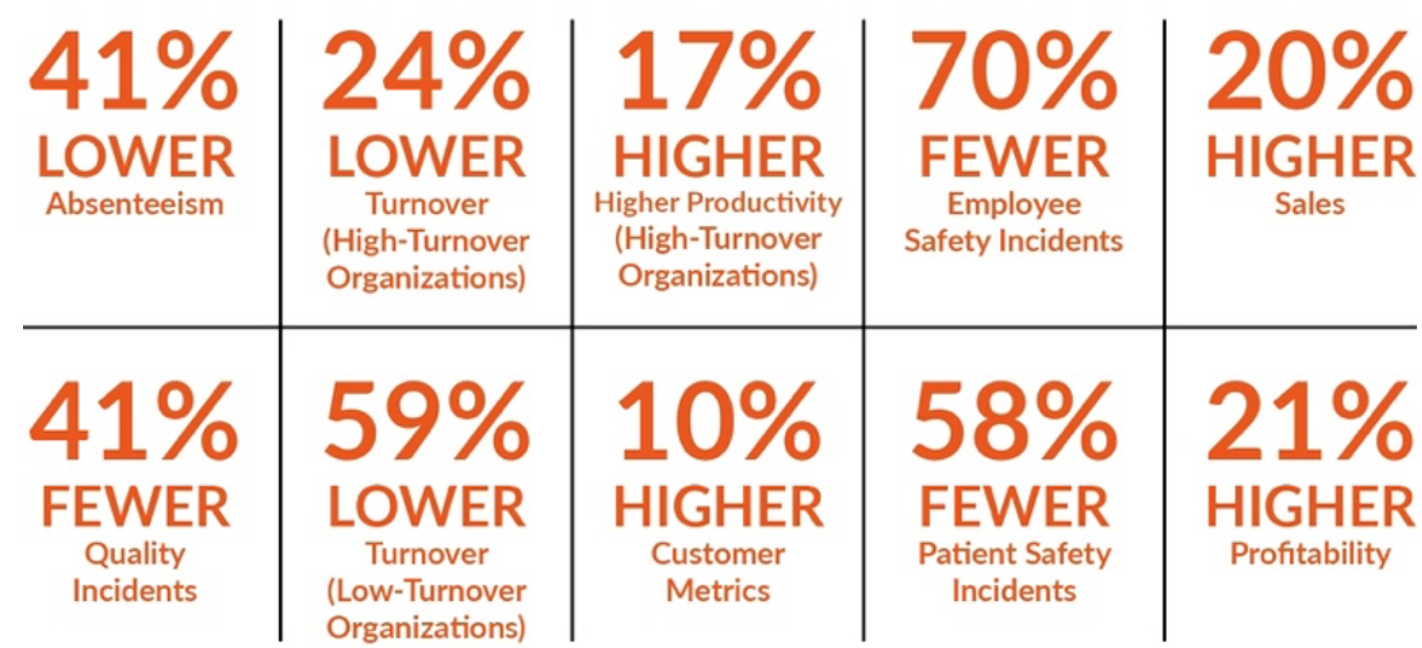

Source: (Gallup Result on Employee Engagement, 2017)

Employees who are engaged are those who psychologically animate their work. They do their job happily, wholeheartedly, and all out. They proactively set high-performance standards for themselves and continue to improve them. The keywords are dedication, energy, and complete (Bakker, Albrecht, \& Leiter, 2011).

\section{Work Engagement}

Discussing employee engagement cannot be separated from the work context. For this reason, we discuss a little about work engagement, which is associated with positive character, dedication, commitment, and completeness in achieving targets or goals, people who can always be relied upon (Schaufeli \& Bakker, 2010; Schaufeli, Salanova, Gonzalez-Roma, \& Bakker, 2002).

Employee engagement is also a result of one's experience in carrying out their work. Jobs that for him are more than just a source of income. Work that gives it meaning and inner satisfaction. His joy, energy, and creativity overflow. A totality (Bakker et al., 2008).

A person who engages will colors and influences the surroundings positively. He or she is a source of inspiration and energy for others to achieve better and best results (Bakker, 2009; Schaufeli et al., 2001).

An engaged person seems to work hard, even always ready to give more. This is for them not a burden or some kind of workaholic, but a motive for achievement and self-actualization. His strength comes from within him. They have their own weather (Gorgievski, Bakker, \& Schaufeli, 2010).

At this point, a hypothesis can be built that there is a close link between the employee's psychology and his or her work and that it will affect his/her performance. The level of happiness and stress of employees in their daily work can be closely related or can be proposed as a predictor or indicator of engagement levels. (Massingham \& Tam, 2015).

In responding to the possibility that an application or AI-based technology could assist SML management, Mr. Siu Min said, "Ideally, we want happy, motivated employees who are also engaged. So, the question becomes - how do we make that happen?"

\section{Drivers of Engagement}

In this case study, SML collaborates with Feet's (www.feets.me), which provides an AI-based application to help SML management know the 
mental state of employees in real-time. In brief, after analyzing data from thousands of employees, the founders of Feet's conclude that happy employees are more productive and committed. One of their major perspective is based on the following research by Arnold B. Bakker, a Dutch industrial and organizational psychologist and Professor of Work and Organizational Psychology at Erasmus University Rotterdam.

The level of engagement of an employee is greatly influenced by his work and personality (Bakker \& Demerouti, 2008; Bakker \& Leiter, 2010).

- Work aspect related to the type and nature of the work he does, namely whether the work helps him to achieve his big goals and develop him over time. So, there is a meaning he appreciates in work (Bakker \& Demerouti, 2007).

- Personality aspect or psychological state which includes several things such as self-confidence, optimism, perseverance in fighting, all of which are very necessary for someone to achieve success through work (Luthans, Youssef, \& Avolio, 2007).

Understanding that there are many factors that can affect an employee's level of engagement, Bakker provides several premises that need to be considered in building measurement tools related to employee engagement.

Premise 1: Engagement is a psychological state that has two dimensions: energy and identification.

Premise 2: Engagement measurement covers two aspects of psychological state, positive and negative.

Premise 3: A person's psychological state is dynamic and temporal.

Premise 4: A "climate," which affects the level of engagement, covers several areas related to work and work environment.

Premise 5: Leadership greatly influences the level of employee engagement.

Premise 6: The team greatly influences the level of engagement of its members.

Premise 7: Engaged employees proactively manage and increase their performance-to continually engaged.

Premise 8: Engagement is limited by other responsibilities or self-limitations.

Premise 9: Engagement must also be linked to the state of employee health, physical and psychological.

Premise 10: Engagement drives high performance.

Based on the ten premises above, SML and Feet's develop a framework for building hypotheses and measuring tools, as follow:

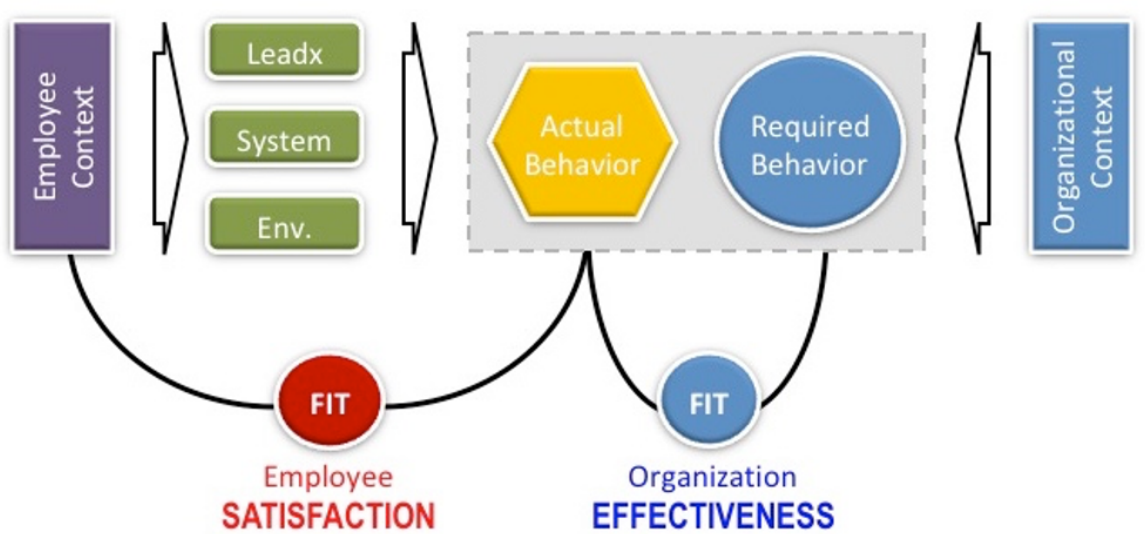

Figure 5. Employee Satisfaction \& Organizational Effectiveness Framework 
The ten premises in correlation with the framework is as follow:

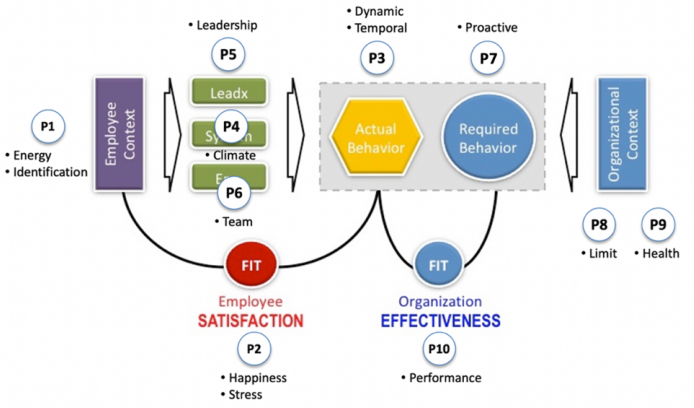

Figure 6. The 10 Premises Framework

Based on the above discussion, we use the Feet's application that measures several major factors with the following relationships (Figure 7).

\section{METHODS}

\section{Measurement tool}

This qualitative research began with in-person or video call interviews with participants. Every conversation was recorded and analyzed to understand how and what management and employees think about happiness, stress, and employee engagement level at SML. The participants interviewed consisted of the CEO, Managing Director, Head of the HR team, and selected staff from SML. The interview questions specifically asked how each participant thought about working at SML related to happiness level, stress level, response to the company, which would then affect employee engagement level, and how do these things impact the key person turnover rate and key person performance. Interviews were conducted using Bakker's theoretical approach with ten premises, as shown in the literature review, which were then linked to the questions generated by the AI-based Feet's application. The interview result data is then compared with the application result data.

Feet's as an AI-based application is used as a comparison tool for interview results. The data generated by the application comes from a survey that is given every month to all SML employees, with a total of 39 employees with the composition shown in Figure-2. The total question bank contained in the Feet's application is more than 700 variations of questions. Every month the application will generate questions for each employee based on their previous answers. In this case, the AI features are contained in the application function. Because the application reads employee behavior patterns from the answers, they send in the questionnaire. The application will process the data every month, so that important information appears, such as stress levels, happiness levels, response rates, and employee engagement levels. The results are then used by SML management as input in strategic decision making.

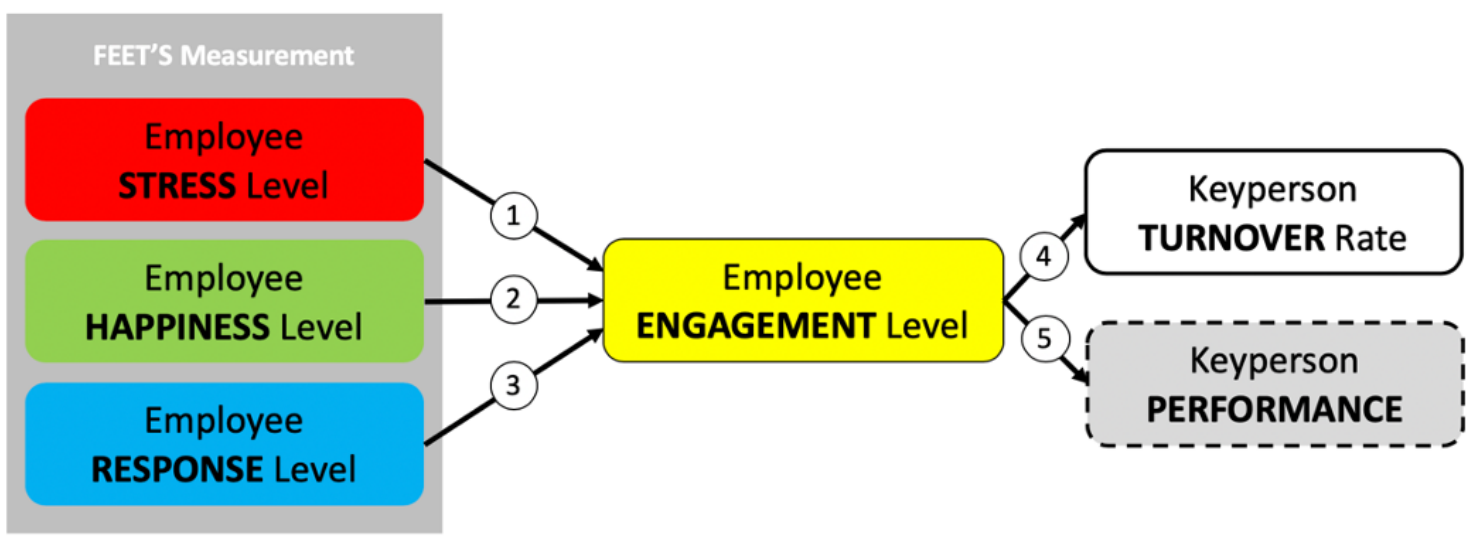

Figure 7. Hypothesis to Increase Engagement \& Performance and Decrease Turnover 
Researchers used data collected by Feet's application in SML for six months, February - July 2020. From the data that has been generated then the researcher will compare it with one by one interview data of SML employees and see whether the data from this AI-based application is in line with the interview data and have a positive impact on the company.

\section{Subject and procedures}

The purpose of this study was to see how the AIbased technology, tools and software, can help management to detect intangible things such as happiness level, stress level, employee engagement level, and provide clues as to what factors influence it and how management can improve it, if necessary. The study was conducted in 2 stages, namely interview sessions and data analysis from AI-based applications. Participants for the interview session came from selected SML management and staff. Selection is taken randomly for each level, from CEO to staff. All selected employees are then subjected to one-on-one interview sessions. Meanwhile, the participants for application data were all SML employees, totaling 39 people. All SML employees are very cooperative and participate actively during the data collection process. The results of the capture of the application can be seen in Exhibit 2. Data collection was carried out during a period of 6 months, from February - July 2020.

\section{RESULT OF USING AI FOR EMPLOYEE ENGAGEMENT}

\section{Identification of employee engagement}

Using the Feet's application tool, data is taken starting from the month of February until July 2020. On a monthly basis, we get data on overall employee engagement rates (averaged) compared to key person engagement levels; in this case, salesperson in general (averaged).

Figure- 8 and figure- 9 show the results of extracting Feet's application data. From figure-9, it can be seen that if stress levels increase, the happiness and engagement levels decrease. We take the example from June to July. Stress level increased from $23 \%$ to $28 \%$, happiness level decreased from $77 \%$ to $72 \%$, and engagement level also decreased from $74 \%$ to $69 \%$. Based on the factors that emerge and are the cause of these numbers, for example: there are toxic spreading around the staff that we can see from the level of engagement that lower than the

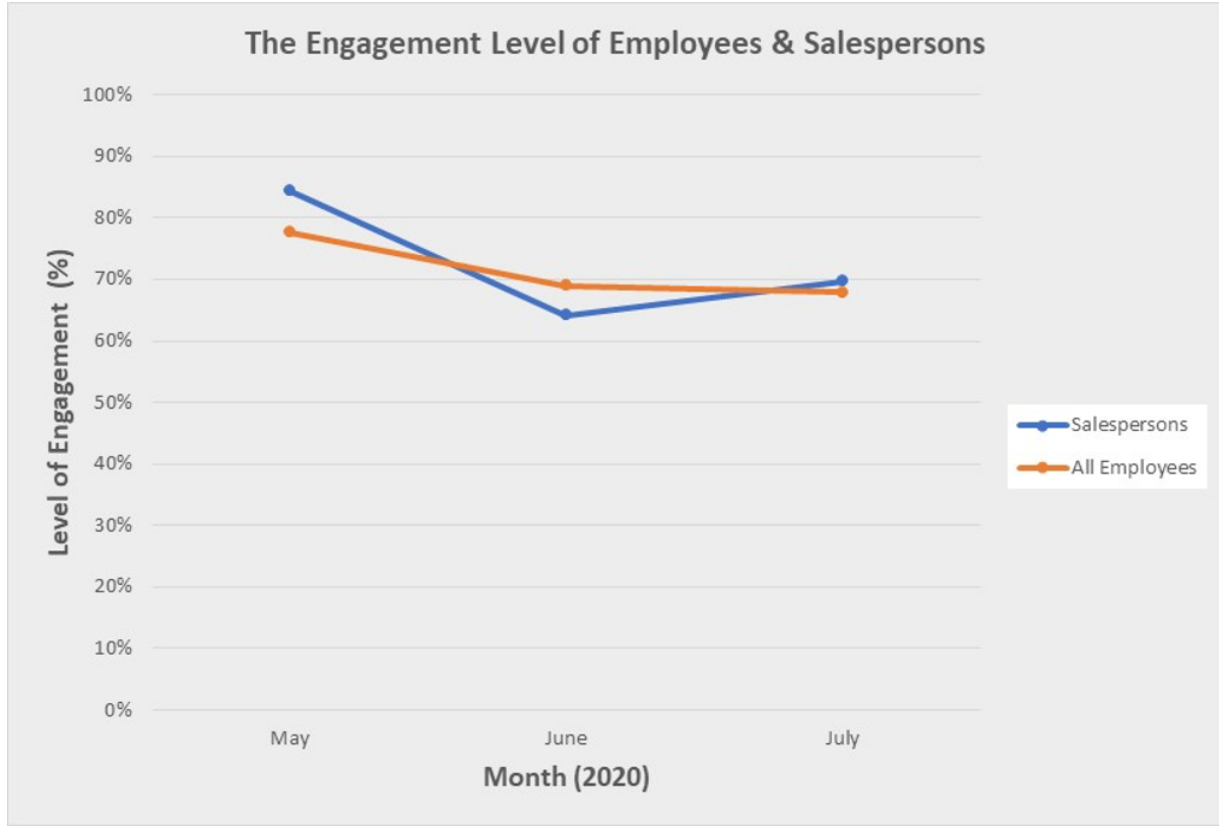

Figure 8. The Engagement Level of Employees \& Salespersons (May - July 2020). 


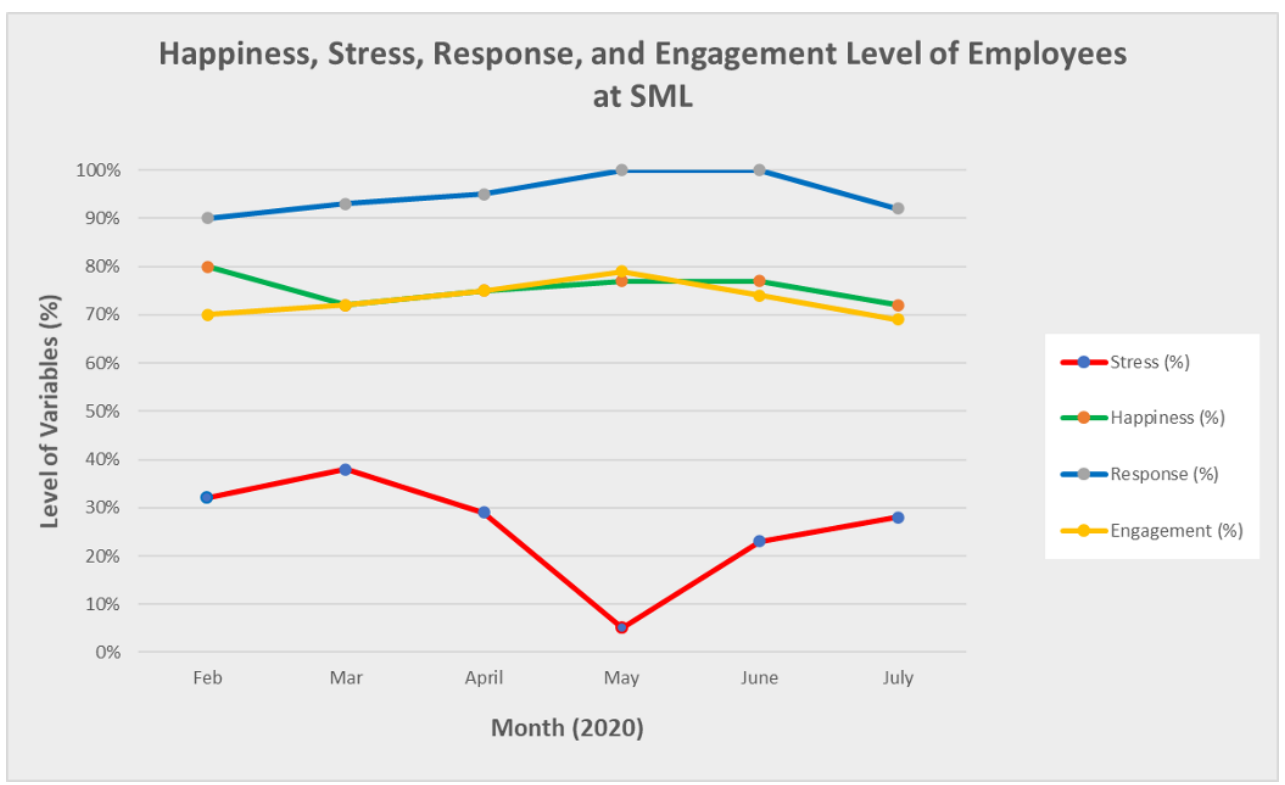

Figure 9. The Percentage of Happiness, Stress, Response, and Engagement Level of Employees at SML (Feb - Jul 2020).

previous month and some point of intention, then the management of SML immediately followed up on the findings in the following month by carrying out several interventions, for example changing the way of communication between staffs. We can see the results in the following month that the numbers are improving.

SML management feels the benefits of using this technology because not only can they detect these four factors in real-time, but they can see the underlying issues that are present in the employees. Ms. Fitri, HR department, said, "So far we have only been able to guess what exactly is on the minds of employees, especially related to factors that can make them stressed or vice versa that can make them happy. With this application, we are very easy to detect these things."

"Through this pilot project, mainly because measurements were also carried out during the pandemic, and it has been proven that we can, proactively, maintain such a high level of employee engagement, we are pretty sure that our team is solid and ready to continue to develop," said Mr. Siu Min.
"What I like the most, I have no background in psychology or HR sciences, and I can understand and practically and creatively, I can make the interventions that are needed, especially for matters related to my position and role as CEO. "continued Mr. Siu Min.

"Speaking of salesperson turnover, which is what triggers the idea of this pilot project, these green children are happy and calm. From the data, there is no indication that anyone wants to leave this company. They focus on achievement, even during this pandemic. Even though their work types and ways of working have changed, they are still enthusiastic. Hopefully, this continues because we are on the right track in leading them. "Ms. Tanti, the Chief Operation, gave her opinion.

Meanwhile, other researchers such as Sharlyn Lauby, author of the HR Bartender blog and president of ITM Group Inc., put happiness, motivation, and engagement as three equal factors needed to become successful employees. So it is very possible that happy employees do not engage, or conversely, those who engage are not necessarily happy (Lauby, 2012). 
Lately, employee engagement has been equated with the employee experience. In this case, the employee's experience will create psychological conditions or conclusions in him, which will determine the level of engagement. So, it is not surprising that many discussions and plans of many organizations to create an employee experience that supports the higher level of employee engagement (StaffConnect, 2018)

\section{Pilot project performance}

The pilot project can go well according to plan. Factors that need to be measured to obtain the data needed can be obtained with high support by employees and SML management. Assistance from partners, in this case, Feet's as an application provider that is used is also very cooperative. Thus, overall it can be said that the process of the pilot project was successful.

There are some allegations that are not proven. For example, we suspect that during a pandemic, between months of February and July, where employees experience changes, both in the type of work, place, and way of working, as well as their social environment, their stress levels will significantly increase. Apparently not. We can see from the Figure-9 chart.

Through several interviews, we found that in addition to causing problems, this pandemic also provided compensation that employees felt was a benefit. For example, by having to work at home, they can reduce the risk of contracting, can manage time more flexibly, save energy from transportation, and more time with family. All of that just increases their happiness. Commitment to the task is maintained.

For SML management, the use of technology has helped them to make decisions and actions more quickly and accurately, especially related to maintaining and increasing employee engagement. Some interventions that were not thought of before and proved to be very effective, for example, a video conference meeting, an intent webinar, social media promotion, etc.

Ms. Yulia, Managing Director, said, "Regarding the Feet's application, we don't feel disturbed or burdened to respond, even if we have to do every day, because the way and activities are fun. We don't feel watched. We feel understood by management. Work gets more excited.“

Mr. Gunawan, the most senior team, said, "It was not like this before. If we have ideas or feel that this and that are lacking, we are also confused about talking. Now with this application, we can convey frankly to management without fear of risk. After all, for the common good."

From the ten premises, according to Arnold Bakker above, the following have experienced significant improvements, sorted from numbers 1 to 10 according to the magnitude of its improvement.

Tabel 1. The improvement of ten premises of SML

\begin{tabular}{lll}
\hline P1 & Employee motivation (energy, empowered) & 9 \\
\hline P2 & Employee satisfaction (happiness) & 9 \\
\hline P3 & Employee behavior (properly, professional) & 8 \\
\hline P4 & Company Policy, system, procedures (as enabler) & 8 \\
\hline P5 & Leadership style (contextual) & 8 \\
\hline P6 & Working environment (positive, synergy) & 8 \\
\hline P7 & Employee proactivity (self-learning, high achiever) & 8 \\
\hline P8 & Employee performance (excellent, by design) & 8 \\
\hline P9 & Employee wellbeing (positively balance) & 8 \\
\hline P10 & Organization performance (profit, growth, sustain) & 9 \\
\hline
\end{tabular}


The usefulness of AI-based technology for decision making

The use of AI-based technology in this pilot project provides a positive and beneficial experience for SML management. What is most feared in this initiative is the resistance of employees who see from the negative side, namely feeling watched and threatened, resistance from field leaders who see this as an additional burden on their busy lives, as well as inaccurate results so that instead of helping even damaging what which has existed.

For that, Mr. Siu Min takes a soft and friendly approach, uses leadership styles that are appropriate for millennials, and engages leaders from the initial discussion to both believe that this initiative is wellintentioned and worked together to produce the best for themselves.

"I am a practical person. If there is an easier way, why do you have to trouble yourself? The important thing is that it is logical, usable, and provides the necessary results. An example is this application. Many have suggested to me beforehand that this cannot be and unusual, but what's wrong with learning and trying new things, and it turns out I can, the results are real and better, so I'm more certain that there are parts that we, humans, have to do, but there is something that can be helped with technology, and the results will be much better, faster, and ultimately more efficient. "Mr. Siu Min emphasized the benefits of this technology-based initiative.

Furthermore, Mr. Siu Min said, "With the help of technology like this, a lot of my time as a leader can be more focused on the things that haven't been much helped by technology, such as thinking about the company's business further progress and journey, innovations that urged to be done, and many other strategic things."

\section{MANAGERIAL IMPLICATIONS}

The study aims to detect employee engagement rates, especially key people. This research's importance is because the research is in the sales section, which is the spearhead of SML. In the event of a large turnover, it can cause the company problems at a later date. The costs incurred to fill vacant employee positions (from the recruitment process to the process of training employees to produce performance according to the company's needs) are very bear.

Some of the advantages of using Feets application for management of SML are:

1. Feets application can help to recognize, engage, and empower the role of employees within the company. Through better engagement with employees, the companies will reduce their employee turnover rates.

2. Feets application can help management of SML hear and engage with their employees, thus creating a better, more enjoyable, and productive work environment.

3. With Feets application, happiness factors in place and aims to foster good relationships between managers and their colleagues at work.

4. The application also offers a new motivation source and creates a culture that drives employee performance for the company's growth in short and real-time.

If SML can detect employee engagement and understand what factors can be improved, then the company will be able to retain its best employees in the long run. With lower sales force turnover, the company can expect to maintain sustainability growth with over USD 15 Million of specialty chemical business revenue.

\section{CONCLUSION}

This case study begins with the subject of employee engagement, which is understood as one of the factors that greatly influence a person's loyalty to work and the company and the level of performance. The research shows evidence that there is a strong relationship between the feeling of everyday employees with the level of engagement 
and participation. The higher their happiness level, the higher their level of engagement and participation. Conversely, the higher their stress level, the lower their level of engagement.

Especially for SML, where this case study was conducted, on the level of engagement and employee participation, the effect of stress is more significant than the effect of happiness. This finding is very good for management to know as an indication of how they will be able to pay attention and effort more effectively.

With the help of AI technology, management can now easily and clearly monitor the condition and movement of employees' daily feelings with better confidence about what factors directly and greatly affect their happiness and stress. Management can even anticipate earlier if there is dissatisfaction that will trigger toxic conversations that will lead to a toxic climate. With a much more effective approach, someone who is anxious can be managed more quickly and more accurately (specific to each personal character and issues). The effect of spreading the toxic conversation can be localized or even prevented.

The management of SML also believes that the conditions and level of employee engagement have an effect on their level of performance, although how direct and how fast the effect needs to be further research.

In this case study, there are indeed four factors that are related and measured and have an influence on key person turnover, namely salesperson. But the relationship between these four factors can be debated between which one precedes which, and which is equivalent to which. Further research is certainly indispensable, especially if we want to delve deeper into the factors that exist in each of them.

In the midst of the many definitions of employee engagement and the factors that influence it, the case study at SML gives us an idea that there are factors that typically affect more than one person or one organization in a situation, which may be different for others, other organizations or other situations. By recognizing its uniqueness, SML management can more effectively manage the engagement of its employees. Studies for time throughout the year are highly recommended if SML wants to understand itself, in the context of this research, for time throughout the year. The second result is that the use of technology can be very helpful. Trials on a broader or complex scale will greatly enrich this experience. For example, if the same application is used in a more mature company, with a diverse business, and with a wider employee demographic. 
REFEREN CES

Bakker, A. B., Albrecht, S. L., \& Leiter, M. (2011). Key questions regarding work engagement. European Journal of Work and Organizational Psychology, 20(1), 4-28. Retrieved from https://www.researchgate.net/publication/232938425_Key_ questions_regarding_work_engagement/link/5e6273514585153fb3c50f67/download

Bakker, A. B., \& Leiter M. P. (2010). Work engagement: A handbook of essential theory and research. New York: Psychology Press.

Bashir, U., \& Ismail Ramay, M. (2010). Impact of stress on employees job performance: A study on banking sector of Pakistan. International Journal of Marketing Studies, 2(1), 122-126. Faculty of Management Sciences, International Islamic University Islamabad, Pakistan.

Changing The Way You Communicate. (2019). Retrieved April 20, 2020, from https://feets.me/about.html

Employee Engagement Survey. (2018). Retrieved July 31, 2020, from https://www.staffconnectapp.com/employeeengagement-survey-results/.

Faslah, Roni. (2010). Hubungan antara Keterlibatan Kerja dengan Turnover Intention pada Karyawan PT. Garda Trimitra Utama, Jakarta. EconoSains,Vol. VIII, No.2, hal 146-151.

Federman, Bard.(2009). Employee Engagement: A Road For Creating Profits, Optimizing Perfomance, And Increasing Loyalty. San Fransisco: Josey Bass

Gallup. (2013). State of the global workplace. Washington, D.C.: Gallup.

Gibson, James L., John M. Ivancevich, dan James H. Donnelly. (2003). Organizations Behaviour, Structure and Process. 8th ed. Boston: Richard D. Irwin Inc.

Kahn, W. A. (1990). Psychological Conditions of Personal Engagement and Disengagement at Work. Academy of Management Journal, 33(4), 692-724.

Kazmi, R., Amjad, S., \& Khan, D. (2008). Occupational stress and its effect on job performance a case study of medical house officers of District Abbottabad. J Ayub Med Coll Abbottabad, 20 (3), 135-139

Lauby, S. (2012, May 10). Happy employees are not engaged employees. Retrieved July 25, 2020, from https://www.hrbartender. com/2012/recruiting/happy-employees-are-not-engaged-employees/

Lockwood, N. R. (2007, March). Leveraging Employee Engagement for Competitive Advantage: HR's Strategic Role. HR Magazine, 52(3), 1-11

Lyubomirsky, S. (2008). The how of happiness: A scientific approach to getting the life you want. New York: Pinguin Books.

Markos, S., \& Sridevi, M. S. (2010). Employee Engagement: The Key To Improving Performances. International Journal of Business and Management, 5 No. 12, 89-96. Thomas, C. H. (2007). A New Measurement Scale for Employee Engagement: Scale Development, Pilot Test and Replication. Academy of Management Proceedings.

Massingham, P. R., \& Tam, L. (2015). The relationship between human capital, value creation, and employee reward. Journal of Intellectual Capital, 16(2), 390-418. Retrieved July 01, 2020, from https://ro.uow.edu.au/cgi/viewcontent.cgi?article=1 $746 \&$ context=buspapers

May, D.R., Gilson, R.L., \& Harter, L.M., (2004). «The psychological conditions of meaningfulness, safety and availability and the engagement of the human spirit a work», Journal of Occupational \& Organizational Psychology. Vol 77, pp. 11-37

Mobley, W.H., (1977). Intermediate Linkages in the Relationship Between Job Satisfaction and Employee Turnover. Journal of Applied Psychology.

Paul, E. (2017, August 05). Effective Ways to Improve Employee Engagement [Web log post]. Retrieved July 01, 2020, from https://www.emptrust.com/blog/employee-engagement-a-key-hr-strategy

Rashid, H. A., Asad, A., \& Ashraf, M. M. (2011). Factors persuading employee engagement and linkage of employee engagement to personal \& organizational performance. Interdisciplinary Journal of Contemporary Research in Business, 3(5), 98-108.

Schaufeli, Salanova, Gonzalez-Roma, V., \& Bakker, A. B. (2002). The Measurement of Engagement and Burnout: A Two Sample Confirmatory Factor Analytic Approach. Journal of Happiness Studies , 3, 71-92.

Schaufeli, W. B. (2012). Work engagement. What do we know and where do we go?. Romanian Journal of Applied Psychology, 14(1), 3-10.

Sekaran, U., \& Bougie, R. (2016). Research Methods for Business (7th ed.). West Sussex, United Kingdom: John Wiley \& Sons Ltd.

State of the American Workplace Report. (2017). Retrieved April 29, 2020, from https://www.gallup.com/workplace/238085/ state-american-workplace-report-2017.aspx 
EXHIBIT

Exhibit 1. Demographic Table of SML

\begin{tabular}{|c|c|c|}
\hline \multicolumn{2}{|l|}{ Characteristic } & Number \\
\hline Gender & Female & 22 \\
\hline & Male & 17 \\
\hline \multirow[t]{4}{*}{ Age } & $<20$ years & 0 \\
\hline & 21 - 30 years & 17 \\
\hline & 31 - 40 years & 13 \\
\hline & 40 and above years & 9 \\
\hline \multirow[t]{4}{*}{ Marital status } & Single & 16 \\
\hline & Single with Kids & 0 \\
\hline & Married w/o Kid & 3 \\
\hline & Married with Kids & 20 \\
\hline \multirow[t]{4}{*}{ Education } & High school & 4 \\
\hline & Bachelor & 30 \\
\hline & Graduate & 5 \\
\hline & Post Graduate & 0 \\
\hline \multirow[t]{7}{*}{ Job title } & CEO & 1 \\
\hline & Directors & 3 \\
\hline & Managers & 4 \\
\hline & Sales & 16 \\
\hline & $\mathrm{BO}$ & 8 \\
\hline & Lab & 2 \\
\hline & Other & 5 \\
\hline
\end{tabular}


EXHIB I T

Exhibit 2. Capture from Feet's Apps for period May, June, July 2020

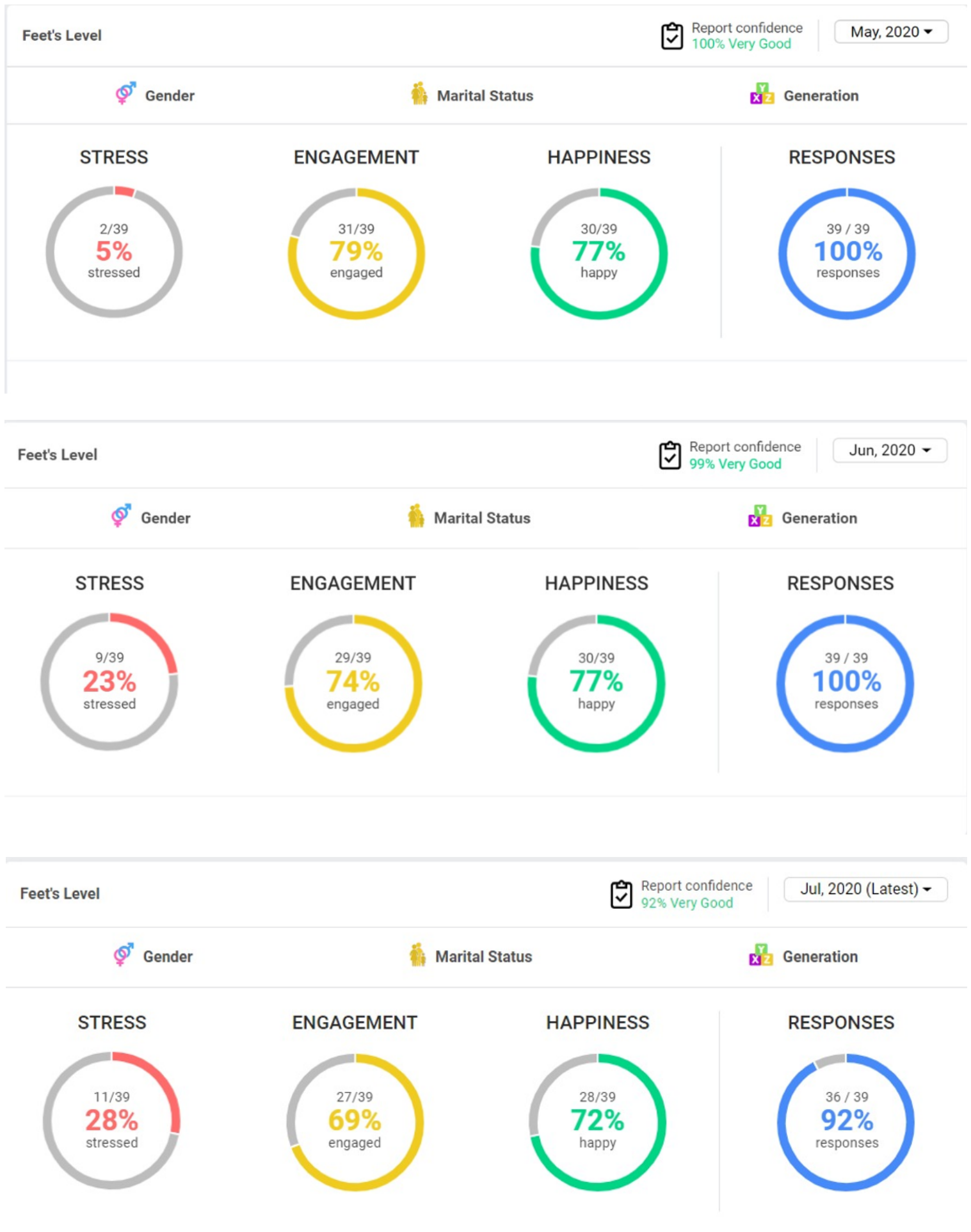

